\title{
An annotated type catalogue of varanid lizards (Reptilia: Squamata: Varanidae) in the collection of the Western Australian Museum
}

\author{
Ryan J. Ellis \\ Department of Terrestrial Zoology, Western Australian Museum, 49 Kew Street, Welshpool, \\ Western Australia 6106, Australia. \\ Email: ryan.ellis@museum.wa.gov.au
}

\begin{abstract}
There are currently 30 recognised species, with 13 subspecies, of varanid lizards (Varanidae: Varanus) occurring in Australia, with 24 known to occur in Western Australia, including five endemic species and one subspecies. Of the 37 Australian varanid species or subspecies, type material for 12 are, or have formerly been, housed in the collection of the Western Australian Museum, including 11 holotypes, one neotype and 67 paratypes. Of the 67 paratypes held in the WAM collection, five belonging to $V$. panoptes rubidus and $V$. glauerti have not been located and are presumed lost. An annotated catalogue is provided for all varanid type material currently and previously maintained in the herpetological collection of the Western Australian Museum.
\end{abstract}

KEYWORDS: type specimens, goanna, monitor lizard, holotype, neotype, paratype, nomenclature

\section{INTRODUCTION}

The varanid lizards (family Varanidae) are represented by a single genus (Varanus) distributed across Africa, the Middle East, South-East Asia and Australia (Pianka et al. 2004), comprising approximately 80 species, of which $30(\sim 37.5 \%)$ and 13 subspecies occur in Australia (Uetz et al. 2018). Australian species include the world's smallest extant varanid, V. sparnus Doughty, Kealley, Fitch \& Donnellan, 2014 (less than $300 \mathrm{~mm}$ total length) and the third largest, Australia's largest, V. giganteus (Gray, 1845) (up to $2.59 \mathrm{~m}$ total length) (Doughty et al. 2014, Pianka et al. 2004). In comparison, the largest living species in the family, V. komodoensis Ouwens, 1912, can attain a total length of up to $3 \mathrm{~m}$ and a mass of 150 kg (Auffenberg 1981, Pianka et al. 2004).

George Shaw (in White 1790) described the first Australian species (Lacerta varia, now $V$. varius) and the generic name Varanus was first established by Merrem (1820). Most early taxonomic work on Australian varanids was carried out by researchers based in Europe until around the end of the 19th century with 13 of the 37 Australian taxa described during this era. This resulted in types nominated from European museums, with few types in the Western Australian Museum (WAM) or other Australian museums from these early descriptions. However, the exception to this is the neotype of Hydrosaurus gouldii $(=V$. gouldii) which was designated from the
WAM collection; it was subsequently gifted to the British Museum (Natural History), now the Natural History Museum, London. Only five currently recognised Australian varanids were described in the early 20th century (1901-1950), while the late 20th century (1951-2000) saw a substantial increase in the number of species or subspecies descriptions, with 16 taxa described. This increase was due to the taxonomic works of the German herpetologist Robert Friedrich Wilhelm Mertens (seven taxa) and WAM herpetologist Glen Milton Storr (five taxa), with single species described by Australian herpetologists Ludwig Glauert, Francis John Mitchell, Max King and Paul Horner, and Richard Walter Wells and Clifford Ross Wellington. The early 21st century (2001-) has already seen the description of three new taxa, all from Western Australia, with type material held in the WAM ( $V$. bushi, V. hamersleyensis and V. sparnus).

The WAM was established in 1891 following the amalgamation of the Museum of the Swan River Mechanics Institute and the Geological Museum. Following the formation of the the WAM, it was originally known as the Public Museum, then Perth Museum and Western Australian Museum and Art Gallery, and subsequently WAM. Since its establishment, the WAM's natural history collection has grown substantially with respect to the terrestrial vertebrate fauna, particularly amphibians and reptiles (How and Cowan 2006). The herpetological collection 
represents one of the largest regional collections in the world and the second largest in Australia, behind the Australian Museum, Sydney (AMS), containing approximately 166,745 specimens (as of September 2018). Following the establishment of the WAM, early donations of material were recorded in a donations register, titled ' 1895 Donations to the Museum'. The earliest entry referring to a varanid specimen is one 'Long tailed Iguana', donated by 'J. L. Salkild [?]' from 'Perth' (early localities often referred to the donor's locality or address, or was an approximation location and not always representative of the specimens precise collection location), dated 6 November 1895. From around 1896 through to 1912, all collected, purchased or donated material, including amphibian and reptile specimens, were accessioned into a series of six hardcopy general registers. The earliest varanid entry in the first WAM acquisition register (Register 1896-1900) was one 'Monitor Gouldii Gould's Monitor (Long-tailed Guana [iguana] or lizard)' from 'Mullewa-Cucky [?]', given to the museum by 'Mr Varden' and dated 25 September 1896. Some earlier entries list only 'lizard' and provide no further information. Earlier acquisitions into the WAM collection were sometimes also published in local press. The earliest such acknowledgement of varanid specimens being donated to the WAM is 'Mr. Varden, long-tailed iguana (monitor Gouldii)' (presumably the same specimen listed in the WAM Register 1896-1900 above), 'W. Cant, Gould's monitor (monitor Gouldii)' and also 'J. Harold, ...Gould's Monitor (monitor Gouldii)', published in the West Australian, 17 November 1896 (Anonymous 1896). No specimens matching the limited donor/collector and locality information of the latter two early acquisitions could be identified within the current varanid collection at the WAM and they are, therefore, presumed lost or disposed.

In 1912 a separate handwritten hardcopy register was established specifically for herpetological specimens and all specimens accessioned into the collection from this point forward were given a registration number prefixed with ' $R$ ' for reptile. The ' $R$ ' prefix is still in use to denote registration numbers and specimens in the herpetological collection, including amphibians. Many specimens from the earlier general hardcopy registers were re-registered into the newer herpetofaunal register and given ' $\mathrm{R}$ ' numbers; however, it is not clear if this was completed for the entire collection. The earliest varanid specimen documented in the WAM herpetofaunal register is R22, two 'Varanus gouldii — young' with the locality 'from the Goldfields' and 'Mr Reece' listed as collector/donor, dated 7 July 1912. The details of most specimens formerly registered in the WAM herpetofaunal register with ' $R$ ' prefixed registration numbers appear to have since been entered into the current electronic database of herpetological specimens, where all new specimens are now registered. The details for some specimens were not entered into the current digital WAM herpetological register, including R22 above, indicating specimens were possibly disposed of or not located prior to or during the transfer, or simply missed during the transfer of data. Currently, the earliest specimen on the WAM digital herpetological register is R330, a specimen of $V$. caudolineatus from Quinns, WA, collected by W.D. Campbell; no collection or accession date is provided, which was common for many early registrations. Specimens in the digital register are mostly listed in sequential order by collection date; some are not, indicating the transfer of records from early registers was not always completed in sequence (e.g. R60218 — collected 1972, R60260 (formerly 11329) — collected 1911, R60280 (formerly 12877) collected 1912, R60348 — collected 1962, R60374 — collected 1978), or the specimen was not offered to the WAM until well after the collection date. The oldest specimen with reference to collection date is R60487, a specimen of $V$. scalaris from Napier Broome Bay, WA, collected in 1910 by G.F. Hill.

The family Varanidae is represented by 2,885 of the 166,745 specimens in the WAM's herpetological collection (as of September 2018), consisting almost entirely of Australian species. The collection contains 2,804 specimens representing 22 species or subspecies collected from Australia, in addition to 78 specimens from Indonesia representing three species ( $V$. indicus, $V$. salvator and $V$. timorensis), one from Malaysia ( $V$. bengalensis), one from Singapore ( $V$. salvator) and one ( $V$. salvator) formerly held by the Perth Zoo from uncertain origin. With the exception of Indonesian specimens collected during museum expeditions, the remaining non-native specimens have been obtained via Perth Zoo, quarantine intercepts or acquired from a deceased estate and lack precise locality data. Of the Australian specimens, 2,683 were collected from Western Australia, 78 from the Northern Territory, 12 from South Australia, 8 from Queensland and 5 from uncertain Australian localities. The majority of varanid specimens are whole specimens fixed in a $10 \%$ formalin solution, though oldest specimens are likely to have been alcohol fixed, and stored in a $70 \%$ ethanol solution, in addition to a small quantity of alizarin-alcian stained, skeletal, skin or mounted specimen preparations of some species. Over 7500 type specimens are held in the WAM herpetology collection with 79 specimens representing types of 12 varanid species or subspecies: 12 primary types (11 holotypes and one neotype) and 67 secondary types (paratypes). Of the 79 type specimens, four paratypes of $V$. panoptes rubidus and the single $V$. glauerti paratype could not be located in the collection and are considered lost.

A partial list of type material held in the WAM herpetological collection compiled by Glen M. Storr was published in WAM annual reports from 1960 
to 1969 , before being discontinued in 1970 with the intention of consolidating existing lists and producing a complete and updated list; this never eventuated (Anonymous 1961, 1970). Annual Report type lists only presented primary type material, with no secondary types listed. They were issued over a series of 10 parts, of which only part 2 (1960-61) included varanid material for three taxa, Varanus (Varanus) gouldi, Varanus mertensi and Varanus (Odatria) timorensis glauerti (Anonymous 1961). Since the 1970 Annual Report, there have been no further publications on the varanid type material held in the herpetological collection of the WAM.

In accordance with recommendation $72 \mathrm{~F}$ of the International Code for Zoological Nomenclature (the Code) (International Commission on Zoological Nomenclature [ICZN] 1999), a type specimen audit was initiated in order to publish a current type catalogue of the material held in the WAM herpetological collection. Audits were undertaken by family due to the large size of the herpetological type collection and the type catalogue will be presented in a series of publications. The first of the series was a type catalogue of the turtles (Chelidae) (Ellis and Georges 2015) followed by the frogs (Anura: Hylidae, Limnodynastidae and Myobatrachidae) (Ellis et al. 2017) and the Gekkota (Squamata: Carphodactylidae, Diplodactylidae, Gekkonidae, Pygopodidae) (Ellis et al. 2018). The current type catalogue is the fourth of this series and presents the type varanid lizards (Squamata: Varanidae) held in the WAM collection.

\section{METHODS}

Information on type specimens was obtained from the original description and compared with information retrieved from accession data in early specimen registers and the current digital herpetology specimen database in addition to jar labels, personal communications and subsequent publications relating to relevant type material. All type specimens in the collection of the WAM were examined in addition to any respective label information and notations. Where specimens could not be located in the type collection, extensive searches of the general collection, accession data, original descriptions and other records were undertaken during the audit to locate missing specimens or those lacking data. This catalogue also includes type specimens of species that have, subsequent to their description, been synonymised and/or resurrected from synonymy with other taxa, or those with type material donated to the WAM since their description. This catalogue was prepared in accordance with the rules, recommendations, definitions and amendments of the Code (ICZN 1999, 2003, 2012).

\section{FORMAT}

This catalogue follows the format of previous WAM type catalogues on herpetological type material held in the WAM collection for turtles (Ellis and Georges 2015), frogs (Ellis et al. 2017), and geckos and legless lizards (Ellis et al. 2018).

\section{ORIGINAL BINOMEN}

\section{Genus species subspecies Author, year}

\section{Original type species citation}

Author, year, title, journal, page(s), [page of description].

\section{Primary type (holotype/neotype)}

Registration number, locality (latitude/longitude), collector(s) and collection date.

\section{Secondary type(s) (paratype/s) (number of types in WAM collection)}

Registration number, locality.

\section{Current nomenclature}

Current generic and specific recognition of the species.

\section{Current status}

Current status and validity of the species, synonymies.

\section{Remarks}

Additional information provided on subjects including the history and status of types, location of additional type specimens, ambiguity in type designations and information regarding the synonymy or resurrection of a species or subspecies if necessary and available.

Each taxon is presented with the name provided by the original author(s), followed by the author's name, and year of publication. Species names are given in the exact format in which they were first published. Next, the original type species publication citation is presented displaying the author(s), year, title (of article or book), journal (unless otherwise), page(s) and the page on which the species description commences in square brackets $([\mathrm{x}])$. Primary type (holotype or neotype) information includes WAM registration number, locality, latitude and longitude (in degrees minutes seconds, where recorded to that precision or decimal degrees as provided in the original description), collector(s) name and collection date where known. Primary type localities and coordinates shown in quotes are those presented in the original published descriptions, including errors. Coordinates presented in square brackets $[\mathrm{x}$ ] unquoted are those identified from accession data not presented in the description or subsequently determined based on locality data presented in the description. All dates are presented as day - month - year, month - year or year, as presented in the original description or relevant 
information sources. Secondary types (paratype/s) are displayed showing WAM registration number and locality. Specific locality (latitude and longitude) and collection details (collector and date) are not provided for secondary type specimens. Specimens marked with an asterix (*) are no longer held in the collection of the WAM, due to being gifted to another institution, disposed of by the WAM or lost. Details of specimens no longer held in the collection are discussed further in the Remarks section of each species where information was available. Current nomenclature and status are only presented where a change from the original binomen or trinomen has occurred such as generic changes, specific amendments, changes to species or subspecies status and synonymy or resurrection from synonymy. Remarks include relevant information on issues and errors from original descriptions, specimens, historical remarks or subsequent publications referring to the species or specimens as well as information relating to the synonymy or resurrection of the species or information pertaining to lost or disposed specimens. Where known, tissue samples for type specimens are presented with tissue type, storage method and storage location. Tissue samples for type material that has been depleted is not presented. Square brackets $([\mathrm{x}])$ indicate corrections or additional information presented in the original description or subsequent publications. The prefix $\mathrm{R}$ is used to denote registration numbers corresponding to the specimens in the herpetofauna collection of the WAM. Specimens currently or previously held in other museum collections are prefixed with the institution's abbreviation prior to the institution's registration number for that specimen.

The following acronyms and abbreviations in presenting type information in this catalogue have been used, institution acronyms follow Sabaj (2016).

BMNH former British Museum (Natural History), now Natural History Museum, London, England, U.K.

E east

HS Homestead

ICZN International Commission on Zoological Nomenclature

Is Island

$\mathrm{km} \quad$ kilometres

Mt mount

$\mathrm{N} \quad$ north

NE northeast

NHMUK Natural History Museum (formerly British Museum (Natural History)), London, England, U.K.

NNE north-northeast

$\begin{array}{ll}\text { NNW } & \text { north-northwest } \\ \text { NW } & \text { northwest } \\ \text { NP } & \text { National Park } \\ \text { nr } & \text { near } \\ \text { NT } & \text { Northern Territory } \\ \text { NTM } & \text { Museums and Art Galleries of the Northern } \\ & \text { Territory (formerly Northern Territory } \\ & \text { Museum of Arts \& Sciences), Darwin, NT, } \\ & \text { Australia } \\ \text { NW } & \text { northwest } \\ \text { S } & \text { south } \\ \text { SE } & \text { southeast } \\ \text { SSE } & \text { south-southeast } \\ \text { Stn } & \text { Station } \\ \text { SW } & \text { southwest } \\ \text { W } & \text { west } \\ \text { WA } & \text { Western Australia } \\ \text { WAM } & \text { Western Australian Museum, Perth, WA, } \\ & \text { Australia } \\ \text { WNW } & \text { west-northwest }\end{array}$

\section{ACCOUNT OF TYPE SPECIMENS}

\section{SQUAMATA}

\section{Family Varanidae}

\section{Hydrosaurus gouldii Gray, 1838}

Gray, J.E. (1838) Catalogue of the slender-tongue saurian, with descriptions of many new genera and species. Annals and Magazine of Natural History (Series 1) 1: 388-394 [394].

\section{Neotype}

R131792 (now NHMUK 1997.1), 'Karrakatta [Cemetery], Perth, WA $\left(31^{\circ} 58^{\prime} \mathrm{S}, 115^{\circ} 47^{\prime} \mathrm{E}\right)$ ', G. Thompson, 29 September 1997.

\section{Current nomenclature}

Varanus gouldii, see Duméril and Duméril (1851).

\section{Remarks}

Gray did not designate any type specimens explicitly in the description; Mertens (1958) designated the specimen BMNH 1.17a (reregistered as BMNH 1946.9.7.61 after the Second World War) as the lectotype (Sprackland et al. 1997). Böhme (1991) noted that the lectotype of Hydrosaurus gouldii (Varanus gouldii) designated by Mertens (1958) was a specimen of Varanus panoptes panoptes Storr, 1980, technically rendering $V$. panoptes panoptes a junior synonym of 
H. gouldii. In a case submitted to the International Commission on Zoological Nomenclature (Case 3042), Sprackland et al. (1997) proposed that the lectotype designated by Mertens (1958) be set aside and BMNH $1.17 \mathrm{~b}$ (locality data lacking) be designated as the neotype in accordance with accustomed usage of both names. Shea and Cogger (1998) proposed an alternative neotype, BMNH 1997.1 (formerly WAM R131792) that had accompanying locality data, as well as tissue samples for genetic comparisons, as opposed to other possible material in the BMNH in poor condition and/ or lacking collection and locality data. The ICZN ruled under the plenary power of the commission (Opinion 1948) that all previous type material of Hydrosaurus gouldii Gray, 1838 was to be set aside and BMNH 1997.1 was designated as the neotype for the species (ICZN 2000). Liver of neotype stored frozen $\left(-75^{\circ} \mathrm{C}\right)$ at WAM.

\section{Varanus bushi Aplin, Fitch \& King, 2006}

Aplin, K.P., Fitch, A.J. and King, D.J. (2006) A new species of Varanus Merrem (Squamata: Varanidae) from the Pilbara region of Western Australia, with observations on sexual dimorphism in closely related species. Zootaxa 1313: 1-38 [24].

\section{Holotype}

R108999, 'Marandoo, WA (22³7'S, $\left.118^{\circ} 08^{\prime} \mathrm{E}\right)$ ', G. Harold, 20 June 1991.

Paratypes (3)

R54230, R56834, R62171, Marandoo, WA.

\section{Remarks}

Liver and heart of holotype stored frozen $\left(-75^{\circ} \mathrm{C}\right)$ at WAM.

\section{Varanus (Varanus) gouldii rosenbergi Mertens, 1957}

Mertens, R. (1957a) Eine neuer melanistischer Waran aus dem südlichen Australien. Zoologischer Anzeiger 159: 17-20 [18].

\section{Holotype}

R822, 'Monigup-Pass [Moingup Pass], Stirling Range, Südwest-Australien [Southwest Australia]', WA (34²4'S, $\left.118^{\circ} 07^{\prime} \mathrm{E}\right)$, R. Bradshaw, 1920.

\section{Paratype}

R821, Moir Pass, Stirling Range, WA.

\section{Current status and nomenclature}

Varanus rosenbergi, see Storr (1980).

\section{Varanus hamersleyensis Maryan, Oliver, Fitch \& O'Connell, 2014}

Maryan, B., Oliver, P.M., Fitch, A.J. and O'Connell, M. (2014) Molecular and morphological assessment of Varanus pilbarensis (Squamata: Varanidae), with a description of a new species from the southern Pilbara, Western Australia. Zootaxa 3768(2): 139-158 [150].

\section{Holotype}

R145733, 'Hamersley Range, Weeli Wolli Creek, WA (2252’40"S, 119¹4'24"E)' R.J. Teale and G. Harold, 28 April 2003.

\section{Paratypes (5)}

R125456, 30 km E Newman, WA; R125766, Circular Pool, Dales Gorge, WA; R129628, 120 km NW Newman, WA; R140734, Rocklea Stn, WA; R164579, $8.5 \mathrm{~km}$ NE Mt Rica, WA.

\section{Remarks}

Liver and heart of holotype stored frozen $\left(-75^{\circ} \mathrm{C}\right)$ at WAM. Liver and heart of three paratypes (R125456, $\mathrm{R} 129628$, R140734) stored frozen $\left(-75^{\circ} \mathrm{C}\right)$ and liver of two (R125766, R164579) stored in 100\% ethanol at WAM.

\section{Varanus kingorum Storr, 1980}

Storr, G.M. (1980) The monitor lizards (genus Varanus Merrem, 1820) of Western Australia. Records of the Western Australian Museum 8(2): 237-239 [268].

\section{Holotype}

R60374, ' $10 \mathrm{~km}$ WNW of Timber Creek, NT (15³7'S, 130²3'E)’, M. King, 9 June 1978.

\section{Paratypes (2)}

R63340 (formerly NTM R6682), Turkey Creek, NT; R63341 (formerly NTM R6955), Kununurra, WA.

\section{Remarks}

Two additional paratypes held in the NTM collection (NTM R6681, R6954). One paratype (R63341) is an alizarin-alcian stained skeleton in glycerol solution, with the skin stored separately in $70 \%$ ethanol solution.

\section{Varanus mertensi Glauert, 1951}

Glauert, L. (1951) A new Varanus from east Kimberley, Varanus mertensi sp. n. Western Australian Naturalist 3: $14-16$ [14].

\section{Holotype}

R5819, 'Moola Bulla Cattle Station near Halls Creek, East Kimberley', WA (18 $\left.11^{\prime} \mathrm{S}, 127^{\circ} 30^{\prime} \mathrm{E}\right)$, H.W. Hall, collection date not specified, presented to WAM on 20 February 1936. 


\section{Varanus (Odatria) timorensis glauerti Mertens, 1957}

Mertens, R. (1957b) Two new goannas from Australia. Western Australian Naturalist 5: 183-185 [183].

\section{Holotype}

R12337, 'Wotjulum, West Kimberley, WA' (16²11'S, 1233'ㄹ), A.M. Douglas, 1956.

\section{Paratype \\ R11207*, Wotjulum, WA.}

\section{Current status and nomenclature}

Varanus glauerti, see Storr (1980).

\section{Remarks}

The paratype specimen was not located in the WAM collection and is considered lost. No record of the paratype being sighted during previous general collection or type specimen audits, or evidence the specimen was gifted or disposed could be located.

\section{Varanus panoptes panoptes Storr, 1980}

Storr, G.M. (1980) The monitor lizards (genus Varanus Merrem, 1820) of Western Australia. Records of the Western Australian Museum 8(2): 237-239 [273].

\section{Holotype}

R44792, 'Lake Argyle, WA (1603'S, 12847'E)', L.A. Smith, 9 January 1972.

\section{Paratypes (17)}

R22368, Kimberley Research Station, N Kununurra, WA; R23450, East Point, Darwin, NT; R26782, Grotto Creek, WA; R28033, R28035, Kalumburu, WA; R28009, R28017, R32173, Mt Anderson, WA; R44793-96, R60217-18, Lake Argyle, WA; R47717, $3 \mathrm{~km}$ S Old Lissadell, WA; R50492, R50549, Drysdale River NP, WA.

\section{Varanus panoptes rubidus Storr, 1980}

Storr, G.M. (1980) The monitor lizards (genus Varanus Merrem, 1820) of Western Australia. Records of the Western Australian Museum 8(2): 237-239 [276].

\section{Holotype}

R19132, 'Wilgie Mia, $60 \mathrm{~km} \mathrm{NNW}$ of Cue, WA (260'' $\left.11^{\circ} 42^{\prime} \mathrm{E}\right)$ ', M.H. Williams, 6 March 1963.

\section{Paratypes (19)}

R12907, [S] Fields Find, [Salt River], WA; R13307, Ullawarra [Stn], WA; R13975, New Forest, WA;
R13975a (now R177046), Nalbarra, WA; R14331, Dolphin Is, WA; R14884, $52 \mathrm{~km}$ W Tambrey, WA; R14889, 37 km E Mt Magnet, WA; R14890, [5 km N] Billabong [RH], WA; R21233 [in error, R27233], Wanjarri, WA; R26261*, 11 km E Wittenoom, WA; R30912*, 11 km S Yalgoo, WA; R51524*, 35 km N Ilgararri Creek, WA; R51614*, Peedamulla, [80 km NNE Onslow], WA; R53507, 16 km S Yalgoo, WA; R53508 [in error, R53058], Yinnietharra, WA; R53689, Errabiddy [Stn], WA; R65958, R65960, nr [2.5 km N] Mt Linden, WA; R65959, nr [7.75 km SSE] Mt Linden, WA.

\section{Remarks}

Two paratype registration numbers listed by Storr are erroneous, R21233 is associated with a specimen of Hemiergis initialis initialis (Werner, 1910) (Scincidae) from Kalamunda, WA and R53508 a specimen of Chelodina steindachneri (Siebenrock, 1914) (Chelidae) from Galena, WA. The correct registration numbers for specimens matching the localities provided by Storr are R27233 and R53058, respectively. Two specimens were associated with the registration number R13975 (R13975 and R13975a), both listed as paratypes by Storr. The paratype bearing the registration number $\mathrm{R} 13975 \mathrm{a}$ has been reregistered as R177046. Two paratypes (R13975 and R13975a (now R177046)) have been identified as Varanus gouldii (Gray, 1838). Four paratypes (R26261, R30912, R51524, R51614) could not be located in the WAM collection and are presumed lost or have been disposed of at some point following the description. No record of the missing paratypes being sighted during previous general collection or type specimen audits could be located.

\section{Varanus pilbarensis Storr, 1980}

Storr, G.M. (1980) The monitor lizards (genus Varanus Merrem, 1820) of Western Australia. Records of the Western Australian Museum 8(2): 237-239 [278].

\section{Holotype}

R39782, 'Chichester Range, WA (22 $\left.{ }^{\circ} 03^{\prime} \mathrm{S}, 118^{\circ} 48^{\prime} \mathrm{E}\right)$,' J.C. Wombey, 7 April 1971.

\section{Paratypes (8)}

R10811, Abydos, WA; R13082, R28011-12, R60432, Woodstock [Stn], WA; R14901, Dales Gorge, WA; R20017, Black Hill Pool, WA; R39158, Nullagine, WA.

\section{Remarks}

One paratype, R14901, has since been identified as a specimen of Varanus hamersleyensis Maryan, Oliver, Fitch \& O’Connell, 2014 (Maryan et al. 2014). 


\section{Varanus sparnus Doughty, Kealley, Fitch \& Donnellan, 2014}

Doughty, P., Kealley, L., Fitch, A. and Donnellan, S.C. (2014) A new diminutive species of Varanus from the Dampier Peninsula, western Kimberley region, Western Australia. Records of the Western Australian Museum 29: 128-140 [132].

\section{Holotype}

R168486, 'Coloumb Point, Dampier Peninsula, WA $\left(-17.4277^{\circ} \mathrm{S}, 122.1522^{\circ} \mathrm{E}\left[17^{\circ} 25^{\prime} 39^{\prime \prime S}, 122^{\circ} 09^{\prime} 07^{\prime \prime E}\right]\right)$, R.J. Teale and G. Harold, 10 March 2009.

\section{Paratypes (2)}

R168474-75, Coloumb Point, Dampier Peninsula, WA.

\section{Remarks}

Liver of holotype and both paratypes stored in $100 \%$ ethanol at WAM.

\section{Varanus storri ocreatus Storr, 1980}

Storr, G.M. (1980) The monitor lizards (genus Varanus Merrem, 1820) of Western Australia. Records of the Western Australian Museum 8(2): 237-239 [283].

\section{Holotype}

R42717, 'Argyle Downs airstrip, WA (16²0'S, 12846'E)', D.J. Kitchener, 11 October 1971.

\section{Paratypes (9)}

R13720, Inverway, NT; R40998, Kildurk [Stn], NT; R42764, 28 km SW Argyle Downs, WA; R51266, Bull Flat Bore, Christmas Creek Stn, WA; R57244, Old Theda [Stn HS], WA; R60041, 30 km SE Halls Creek, WA; R60042, Wave Hill Police Station, NT; R60043, Gordon Creek, 28 km S Victoria River Downs, NT; R60044, Gordon Creek, 49 km S Victoria River Downs, NT.

\section{ACKNOWLEDGEMENTS}

I thank Paul Doughty (WAM) for assistance locating specimens, records and data regarding varanid type material in the WAM collection. I also thank Paul Doughty, Aaron Bauer (Villanova University) and Glenn Shea (Sydney University and AMS) for reviewing and providing useful comments on the draft manuscript.

\section{REFERENCES}

Anonymous. (1896, November 17). Donations to the Museum. The West Australian (New Series) Vol. 12(No. 3351): 3.

Anonymous. (1961). Type specimens in the Western Australian Museum (Part 2). Western Australian Museum Annual Report 1960-61: 35-39.
Aplin, K.P., Fitch, A.J. and King, D.J. (2006). A new species of Varanus Merrem (Squamata: Varanidae) from the Pilbara region of Western Australia, with observations on sexual dimorphism in closely related species. Zootaxa 1313: 1-38.

Auffenberg, W. (1981). The behavioural ecology of the Komodo monitor. University Press of Florida, Gainesville.

Böhme, W. (1991). The identify of Varanus gouldii (Gray, 1838), and the nomenclature of the $V$. gouldii species complex. Mertensiella 2: 38-41.

Doughty, P., Kealley, L., Fitch, A. and Donnellan, S.C. (2014). A new diminutive species of Varanus from the Dampier Peninsula, western Kimberley region, Western Australia. Records of the Western Australian Museum 29: 128-140. doi: 10.18195/issn.0312-3162.29(2).2014.128-140

Duméril, A.M.C. and Duméril, A.H.A. (1851). Catalogue méthodique de la collection des reptiles du Muséum d'Histoire Naturelle de Paris. Gide et Baudry/Roret, Paris.

Ellis, R.J. and Georges, A. (2015). An annotated type catalogue of the turtles (Testudines: Pleurodira: Chelidae) in the collection of the Western Australian Museum. Records of the Western Australian Museum 30: 52-60. doi: 10.18195/ issn.0312-3162.30(1).2015.052-060

Ellis, R.J., Doughty, P. and Roberts, J.D. (2017). An annotated type catalogue of the frogs (Amphibia: Anura: Limnodynastidae, Myobatrachidae, Pelodryadidae) in the collection of the Western Australian Museum. Records of the Western Australian Museum 32: 1-28. doi: 10.18195/ issn.0312-3162.32(1).2017.001-028

Ellis, R.J., Doughty, P. and Bauer, A.M. (2018). An annotated type catalogue of the geckos and pygopods (Squamata: Gekkota: Carphodactylidae, Diplodactylidae, Gekkonidae, Pygopodidae) in the collection of the Western Australian Museum. Records of the Western Australian Museum 33: 51-94. doi: 10.18195/issn.0312-3162.33(1).2018.051-094

Glauert, L. (1951). A new Varanus from east Kimberley Varanus mertensi sp.n. Western Australian Naturalist 3: $14-16$.

Gray, J.E. (1838). Catalogue of the slender-tongued saurians, with descriptions of many new genera and species. Annals and Magazine of Natural History (Series 1) 1: 388-394. doi: 10.1080/00222933809512320

Gray, J.E. (1845). Catalogue of the Specimens of Lizards in the Collection of the British Museum. Trustees of the British Museum/ Edward Newman, London.

How, R.A. and Cowan, M.A. (2006). Collections in space and time: geographical patterning of native frogs, mammals and reptiles through a continental gradient. Pacific Conservation Biology 12: 111-133.

International Commission on Zoological Nomenclature [ICZN] (2000). Opinion 1948. Hydrosaurus gouldii Gray, 1838 (currently Varanus gouldii) and Varanus panoptes Storr, 1980 (Reptilia, Squamata): specific names conserved by the designation of a neotype for $H$. gouldii. Bulletin of Zoological Nomenclature 57: 63-65.

Maryan, B., Oliver, P.M., Fitch, A.J. and O'Connell, M. (2014). Molecular and morphological assessment of Varanus pilbarensis (Squamata: Varanidae), with a description of a new species from the southern Pilbara, Western Australia. Zootaxa 3768: 139-158. doi: 10.11646/zootaxa.3768.2.3

Merrem, B. (1820). Versuch eines Systems der Amphibien. J.C. Krieger, Marburg.

Mertens, R. (1957a). Eine neuer melanistischer Waran aus dem südlichen Australien. Zoologischer Anzeiger 159: 17-20. 
Mertens, R. (1957b). Two new goannas from Australia. Western Australian Naturalist 5: 183-185.

Mertens, R. (1958). Bemerkungen über die Warane Australiens. Senckenbergiana Biologica 39: 229-264.

Ouwens, P.A. (1912). On a large Varanus species from the island of Komodo. Bulletin du Jardin botanique de Buitenzorg (Series 2) 6: 1-3.

Pianka, E.R., King, D.R. and King, R.A. (eds). (2004). Varanoid Lizards of the World. Indiana University Press, Bloomington.

Sabaj, M.H. (2016). Standard symbolic codes for institutional resource collections in herpetology and ichthyology: an online reference. Version 6.5 (16 August 2016). American Society of Ichthyologists and Herpetologists, Washington DC. Available at http://www.asih.org/

Shea, G.M. and Cogger, H.G. (1998). Comment on the proposed conservation of the names Hydrosaurus gouldii Gray, 1838 and Varanus panoptes Storr, 1980 (Reptilia, Squamata) by the designation of a neotype for Hydrosaurus gouldii. Bulletin of Zoological Nomenclature 55: 106-111.

Siebenrock, F. (1914). Eine neue Chelodina Art aus Westaustralien. Anzeiger der Akademie der Wissenschaften in Wien 17: 386-387.
Smith, L.A. (1981). A revision of the python genera Aspidites and Python (Serpentes: Boidae) in Western Australia. Records of the Western Australian Museum 9: 211-226.

Sprackland, R.G., Smith, H.M. and Strimple, P.D. (1997). Hydrosaurus gouldii Gray, 1838 (currently Varanus gouldii) and Varanus panoptes Storr, 1980 (Reptilia, Squamata): proposed conservation of the specific nsames by the designation of a neotype for $\mathrm{H}$. gouldii (Case 3042). Bulletin of Zoological Nomenclature 54: 95-99.

Storr, G.M. (1980). The monitor lizards (genus Varanus Merrem, 1820) of Western Australia. Records of the Western Australian Museum 8: 237-293.

Uetz, P., Freed, P. and Hošek, J. (2018). The Reptile Database. Available at: http://www.reptile-database.org/

Werner, F. (1910). Reptilia (Geckonidae und Scincidae). In: Michaelsen, W. and Hartmeyer, R. (eds) Die Fauna Südwest-Australians. G. Fischer, Jena, pp. 451-493.

White, J. (1790). Journal of a voyage to new South Wales, with sixty-five plates of non descript animals, birds, lizards, serpents, curious cones of trees and other natural productions. Debrett, London.

MANUSCRIPT RECEIVED 6 SEPTEMBER 2018; ACCEPTED 10 DECEMBER 2018. 